\title{
PRICE DYNAMICS IN THE ASSORTMENT OF VEGETABLES OF ORGANIC AGRICULTURAL PRODUCTION IN 2014-2016
}

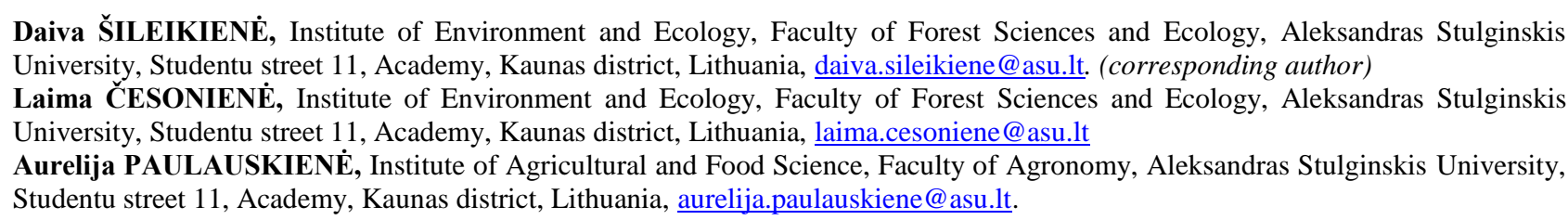

The article analyzes the price dynamics of organic vegetables in Lithuania during the period of 2014 - 2016. A comparative analysis of the prices of organic vegetables (potatoes, carrots, onions) was carried out as well as a comparative analysis of Lithuanian and imported vegetables, the trends of organic potato and vegetable price dynamics were estimated. The research carried out has revealed that lowest price of organic potato during the research period was in spring and winter. Potatoes of new harvest during summer (1.23 EUR/kg) and autumn (1.25 EUR/kg) seasons are higher. Price difference between Lithuanian and imported organic carrots and potatoes during different seasons is insignificant; significant fluctuations have been recorded only in Lithuanian and imported carrots in all period and potatoes in 2015 .

The most expensive vegetables were organic carrots, the average price of which in 2014 was $1.38 \mathrm{EUR} / \mathrm{kg}$. During the research period the average price of organic potatoes was $1.21 \mathrm{EUR} / \mathrm{kg}$, i.e. 2.5 of times more than the conventional carrots $(0.47 \mathrm{EUR} / \mathrm{kg})$. Prices of the imported vegetables were higher than the prices of Lithuanian ones. In the analysed period the price of imported carrots (1.98 EUR/kg) was on average 1.5 times higher than the price of Lithuanian carrots (1.31 EUR/kg), imported organic onions (2.33 EUR/kg) were up to $57 \%$ more expensive than Lithuanian onions $(1.33 \mathrm{EUR} / \mathrm{kg}$ ). Germany has a wider supply of organic products. The price of potatoes in Germany using the analyzed period has risen in 51\%. In 2016, the price of potatoes in Germany was 34\% higher than in Lithuania. During the entire research period the price of organic carrots in Lithuania was higher than in Germany. In 2016, onions in Germany were $16 \%$ more expensive.

Keywords: market, organic products, import, vegetables, potatoes.

\section{INTRODUCTION}

Organic farming system is one of the most environmentally friendly production systems in agriculture. The principle of the organic agricultural production is to adapt to the nature while maintaining clean environment and biodiversity. Organic farming helps in solving environmental and employment problems, provides an opportunity of a healthy lifestyle to people thus contributing to a sustainable development of agriculture (Skulskis, 2014). One of the goals of the Law on Food of the Republic of Lithuania is to ensure the promotion of production of organic agricultural products, healthier nutrition of the population of Lithuania, and improvement of people's health in relation to food and nutrition.

Nowadays, due to the growing levels of environmental pollution the world has a growing interest in the organic agriculture and organic foodstuffs, which are natural and environmentally friendly. Organic foods are rich in minerals and vitamins, they do not contain pesticide residues, heavy metals, hormones, they are not contaminated with synthetic additives (Skulskis, Girgždienè, 2009). The analysis of the use of organic food products revealed that people usually buy organic food for their health, and do not use it because it is expensive. Statistically, significant numbers of younger people use these products, which they mostly purchase at supermarkets and they know how to distinguish organic food from the conventional, but most people still lack information on how to do this. (Stukas, 2010).

An important factor in the consumption of organic products is the price, not only in Lithuania, but in other countries. In Romania, 75\% of consumers say that a higher price of organic products restricts the purchase of these products (Bozga, 2015). A study in France revealed that every second buyer highlighted the cost price of organic products at a higher cost than traditional foods (Kesse-Guyot, Péneau, Méjean, 2013). Danish consumers also emphasize the price of organic products, because these products are too expensive for everyday shopping (Marian, Chrysochou, Athanasios, 2014).

With the growing demand of customers to use more natural products, the range of these products is increasing as well. As a consequence, organic farming is increasingly developing and growing, the number of more natural and diverse

Copyright (C) 2017 The Authors. Published by Aleksandras Stulginskis University. This is an open-access article distributed under the terms of the Creative Commons Attribution License (CC-BY 4.0), which permits unrestricted use, distribution, and reproduction in any medium, provided the original author and source are credited. 
products is growing. It is really difficult to grow an organic product, because specific requirements apply to this type of farming. Firstly, cultivation of soil requires more human physical work and time. Secondly, organic seed itself is more expensive than normal. Moreover, organic farming pays a lot of attention to soil improvement measures, which are also more expensive than the conventional ones. It is worth mentioning that in comparison with the intensive agricultural production system, in case of organic agricultural production, less yield is obtained from the same unit of land area. In organic farming the quality of the yield obtained is more important than its volume. This is determining the ratio of the prices for organic and conventional products (Ekoagros, 2014).

\section{MATERIALS AND METHODS}

Research aim was to analyse and evaluate the peculiarities of organic vegetable market in Lithuania during the period of 2014-2016. Objectives of the research:

1. To carry out a comparative analysis of the prices of Lithuanian and imported organic potatoes and vegetables carrots in different seasons.

2. To determine the trends of prices of Lithuanian and imported vegetables during the research period.

3. To evaluate the trends in price changes in Germany and Lithuania.

Object of the Research is the market of organic potatoes and vegetables (carrots, cabbage, onions).

Analysis of scientific literature and statistical data, grouping of statistical data, graphical modelling and comparison. Sources of the secondary data used in the article: information system of agricultural and food products of the State enterprise Agricultural Information and Rural Business Centre. The data were processed using Microsoft Excel software package.

\section{RESULTS AND DISCUSSION}

In 2015, compared to 2010, the area of the organic agriculture production in the EU countries has increased by $21.10 \%$. The largest organic production areas have been certified in Spain, Italy, France and Germany. The organic production area in Lithuania amounted to $1.92 \%$ of the EU organic production area (Agricultural Information and Rural Business Centre, 2016).

During the period of 2014-2016, potato crop areas have been increasingly decreasing, resulting in decreased yield as well. Potato yield in 2015 was the smallest over the last five years. Smaller yields of potatoes were the reason of higher potato prices in 2015 in other EU countries as well. The decline in potato crop area is associated with the decreasing consumption. Potatoes are increasingly replaced by various vegetables in the nutrition of Lithuanians. Reducing the area of potato crops, the demand for potatoes seed is reduced as well. Moreover, less potatoes are consumed for feed, but despite the decline, in Lithuania the consumption of potatoes is still about $30 \%$ higher than the EU average. The areas of potato crops are decreasing every year, reduced consumption and lower yields, which are still sufficient for the Lithuanian market, show a decreasing demand for potatoes (Lithuanian Institute of Agrarian Economics, 2014).

According to the data of the Lithuanian Department of Statistics, in 2015 potato crops occupied the area of 23.5 thousand hectares, according to the data of the certification body EKOAGROS the crops of organic farming potatoes occupied 303.76 hectares, which is only $1.29 \%$ of all planted potatoes. In 2015 , the yield of potatoes in conventional agricultural production was 399.2 thousand tones, of which organic potatoes amounted to 4143 tones, i.e. $1.04 \%$.

Organic potatoes make up about $1 \%$ of all potatoes harvested. Prices for organic and imported potatoes vary (Fig. 1). Prices of organic potatoes in retail shopping were slightly different from one year to the next, with the largest price differences in different seasons (1.6 Eur/kg in the spring, 1.45 Eur $/ \mathrm{kg}$ in summer and lowest in autumn and winter) set in 2014; prices remained the same for all the years 2015 and 2016. The prices of imported organic potatoes in supermarkets differed substantially from Lithuanian organic potatoes. The biggest price differences for the year are set in 2015, when organic potatoes were more expensive in all seasons compared to the following seasons.

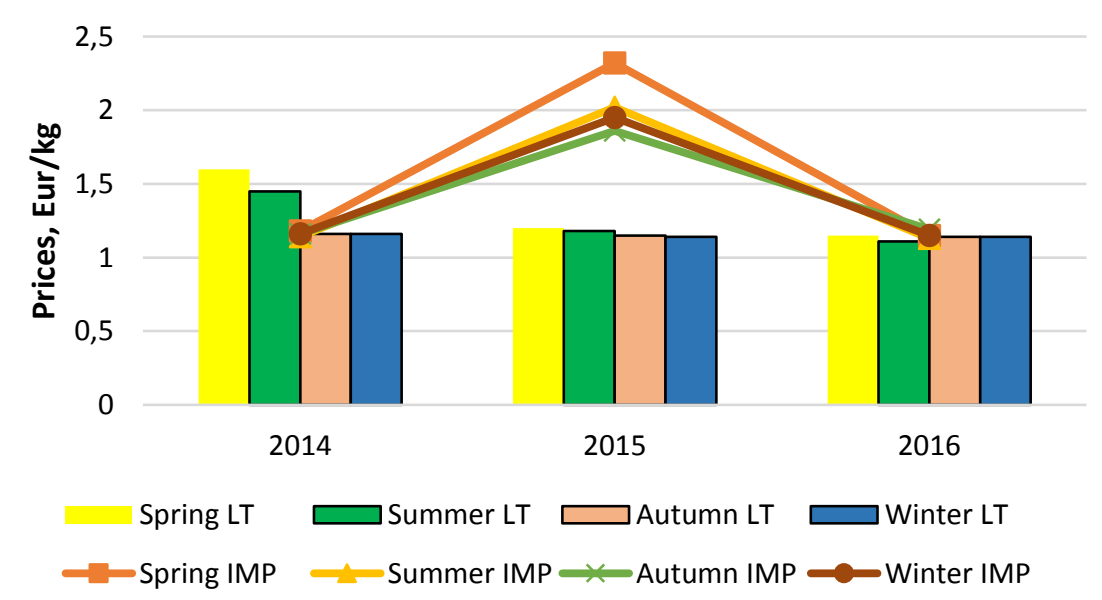

Figure 1. The average prices Lithuanian and imported organic potato production in different seasons period 2014-2016 
According to the data of the State Enterprise Agricultural Information and Rural Business Centre, Fig. 2 shows the changes in prices of Lithuanian and imported organic carrots in retail shopping centres in Lithuania during the period of 2014 - 2016. The price data presented show that the price of organic imported carrots is higher than the price of Lithuanian ones. During the research period, the highest price of organic carrots was in 2014. The price of the importeds (2.7 Eur $/ \mathrm{kg}$ ) was 2 times higher than the price of the Lithuanian ones (1.35 Eur $/ \mathrm{kg}$ ). The cheapest onions were available in 2015, their average prices recorded were $1.32 \mathrm{Eur} / \mathrm{kg}$ (Lithuanian) and $2.05 \mathrm{Eur} / \mathrm{kg}$ (imported) respectively. In 2016, the price of onions increased again, the price of Lithuanian onions increased by almost $1 \%$, while the imported - almost 9\%. The price trends during the research period show that the price of the imported organic onions in 2014 was twice as high as Lithuanian ones.

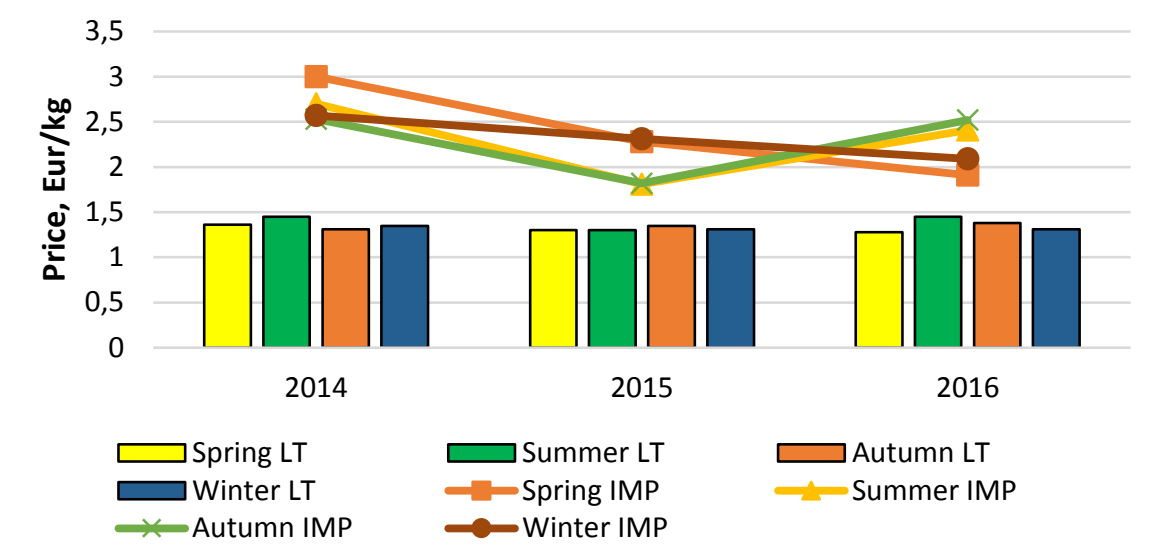

Figure 2. The average prices Lithuanian organic and imported carrots production in different seasons period 2014-2016

During the study, the prices of the organic and the conventional vegetables (potatoes, onions and carrots) grown in Lithuania, recorded in retail shopping centres were compared (Fig. 3). The prices of organic potatoes and organic vegetables are very different from the vegetables of conventional production. To compare the prices of cabbages, there is a 1.7 times difference in 2014 , when the average price of the organic ones was $1.16 \mathrm{EUR} / \mathrm{kg}$ and the price of the conventional ones was 0.7 EUR $/ \mathrm{kg}$. The highest price difference was recorded in 2016, when the price of organic cabbages was $1.13 \mathrm{EUR} / \mathrm{kg}$, i.e. 3 times higher than the price of the conventional ones amounting to $0.37 \mathrm{EUR} / \mathrm{kg}$. The prices of onions were more stable, and were fluctuating less, but the price of organic onions in 2014 was 3.1 times higher than the price of the conventional ones. Prices of organic carrots $(1.38 \mathrm{EUR} / \mathrm{kg})$ in 2014 were 3.2 times higher than the prices of the conventional carrots $(0.43 \mathrm{EUR} / \mathrm{kg})$. Having analyzed the data, it can be stated that Lithuanian organic vegetables are 3 times more expensive than Lithuanian vegetables of conventional production.

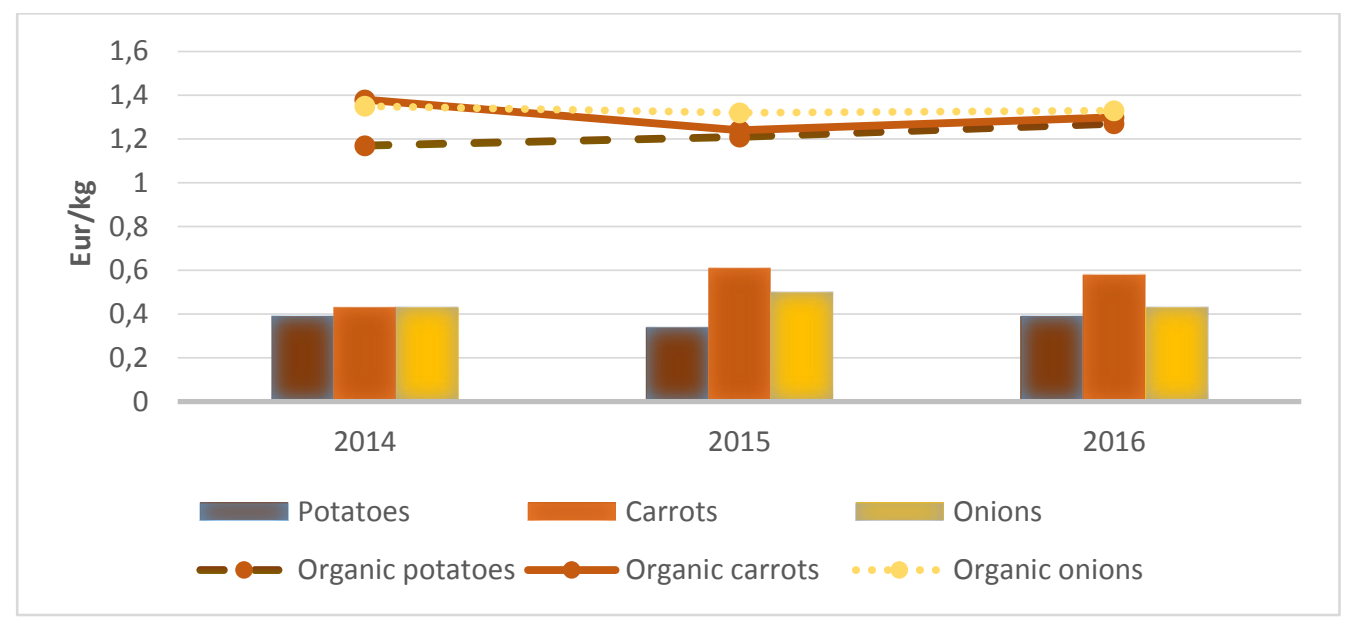

Figure 3. The average prices of Lithuanian organic and conventional production potatoes, carrots and onions (EUR/kg) for period 2014-2016.

Germany is one of the leaders in organic farming. The areas of organic farming in the country in 2012-2015 increased on $10.5 \%$. According to the data of the International Organic Agriculture Federation, in terms of organic farming in the countries of the European Union, Germany occupied the 4th place in 2015 and the 10th place in the world. Among the world's most eco-friendly countries, Germany was 8 th place country in the world in 2015, with an average of 106 Eur, which resident spends for organic products per year. State Enterprise Agricultural Information and Rural Business Center in the Agricultural and Food Market Information System in the foreign market database of organic food products presents the prices of German organic products (www.vic.1t/? mid=467\&id=26038). 


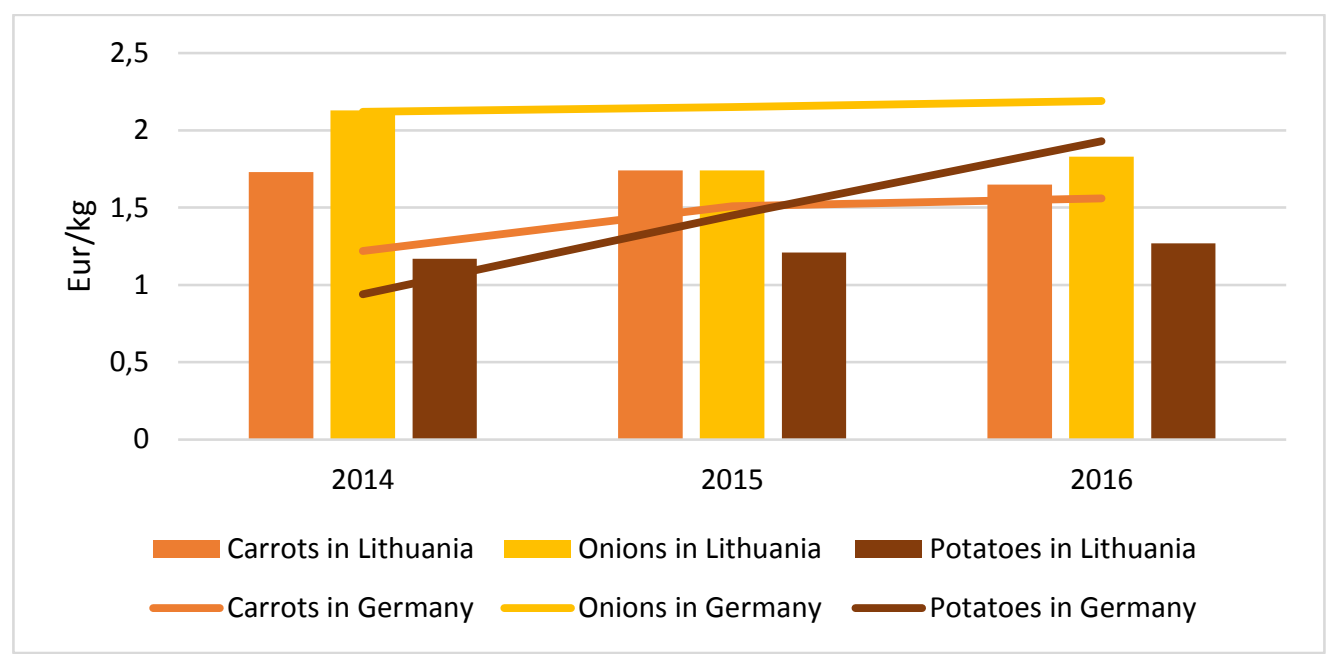

Figure 4. Trends in Prices of Lithuanian and Germany Organic Vegetables in period 2014-2016

German population consumes less potato than Lithuanian population. According to the data of the State Agricultural Information and Rural Business Center, organic farming potatoes in Germany during the analyzed period cost from $0.94 \mathrm{Eur} / \mathrm{kg}$ to $1.93 \mathrm{Eur} / \mathrm{kg}$, they went up by $51 \%$. In Germany and Lithuania potatoes were the cheapest in 2014. Germany consumers paid for them 94 euro cents per kilogram, and in Lithuania - 1.17 Eur $/ \mathrm{kg}$. In 2016 potatoes were $34 \%$ more expensive in Germany than in Lithuania.

The popularity of organic vegetables is growing much faster than production. Most organic vegetables are sold in larger retail chains. In the analyzed period, the price of carrots in Germany increased from 1.22 to $1.56 \mathrm{Eur} / \mathrm{kg}$. In Lithuania the price of carrots decreased from 1.73-1.65 Eur $/ \mathrm{kg}$. In 2014 year carrot prices were the lowest in Germany, the largest in Lithuania. In 2016, the Germans bought carrots at the most expensive prices, and Lithuanians could enjoy the cheaper prices. In 2014-2016, organic carrots in Lithuania were more expensive than in Germany.

The areas of onions grown in many European countries are increasing, and this trend is recorded in Germany and Lithuania too. The increase in onion area affected the higher quantities. In Germany, the price of organic farming onions increased slightly from 2.12 to 2.19 Eur $/ \mathrm{kg}$ during the period of 2014-2016. In Lithuania, the price of onions for this period decreased by $14 \%$, from 2.13 to $1.83 \mathrm{Eur} / \mathrm{kg}$.

\section{CONCLUSIONS}

The lowest price of organic potato during the research period was in spring and winter. Potatoes of new harvest during summer $(1.23 \mathrm{EUR} / \mathrm{kg})$ and autumn $(1.25 \mathrm{EUR} / \mathrm{kg})$ seasons are higher. Price difference between Lithuanian and imported organic carrots and potatoes during different seasons is insignificant; significant fluctuations have been recorded only in Lithuanian and imported carrots in all period and potatoes in 2015.

The most expensive vegetables were organic carrots, the average price of which in 2014 was $1.38 \mathrm{EUR} / \mathrm{kg}$. During the research period the average price of organic potatoes was $1.21 \mathrm{EUR} / \mathrm{kg}$, i.e. 2.5 of times more than the conventional carrots $(0.47 \mathrm{EUR} / \mathrm{kg})$. Prices of the imported vegetables were higher than the prices of Lithuanian ones. In the analysed period the price of imported carrots $(1.98 \mathrm{EUR} / \mathrm{kg}$ ) was on average 1.5 times higher than the price of Lithuanian carrots $(1.31$ EUR/ $/ \mathrm{kg}$ ), imported organic onions ( $2.33 \mathrm{EUR} / \mathrm{kg}$ ) were up to $57 \%$ more expensive than Lithuanian onions (1.33 EUR/kg).

Germany has a wider supply of organic products. The price of potatoes in Germany using the analyzed period has risen in $51 \%$. In 2016, the price of potatoes in Germany was $34 \%$ higher than in Lithuania. During the entire research period the price of organic carrots in Lithuania was higher than in Germany. In 2016, onions in Germany were $16 \%$ more expensive.

\section{REFERENCES}

1. Bozga N-A. 2015. The Perception of Romanian Consumer upon Organic Products' Prices. Procedia Economics and Finance, Vol. 27, pp. 323-333. https://doi.org/10.1016/S2212-5671(15)01003-5

2. Kesse-Guyot E., Péneau S., Méjean C., Edelenyi F.S., Galan P., Hercberg S., Lairon D. 2013. Profiles of Organic Food Consumers in a Large Sample of French Adults: Results from the Nutrinet-Santé Cohort Study.

3. Marian L., Chrysochou P., Athanasios K., Thøgersen J. 2014. The Role of Price as a Product Attribute in the Organic Food Context: An Exploration Based on Actual Purchase Data. Food Quality and Preference, Vol. 37, pp. 52-60. https://doi.org/10.1016/j.foodqual.2014.05.001

4. Skulskis V., Girgždienè V., Mikelionytè D. 2014. Performance evaluation results of the organic dairy cooperative. Management Theory and Studies for Rural Business and Infrastructure Development, Vol. 36, No. 2, pp. 407-415. https://doi.org/10.15544/mts.2014.037

5. Skulskis V., Girgždienė V. 2009. Consumption of Organic Food Products And Related Information Sources In Lithuania. Agricultural Sciences, Vol. 16. No. 3-4, pp. 154-161 
6. Stukas, R., Šurkienè, G., Dubakienè, R., Nagytė, R., Baranauskas, M. (2010). Consumption and assessment of organic food by adult residents of Vilnius (Lithuania). Ekologija, Vol. 56. No. 1-2.

7. Všs „Ekoagros“. 2014. Organic farming in Lithuania.

http://www.ekoagros.lt/uploads/file/Ekologinis\%20ukininkavimas\%20vartotojui.pdf (2017-03-08).

8. State Enterprise Agricultural Information and Rural Business Center. https://www.vic.lt/?mid=461\&id=23204.

9. The Lithuanian Institute of Agrarian Economics. Agriculture and food sector in Lithuania 2015.file:///C:/Users/VARTOT 1/AppData/Local/Temp/Lietuvos žemès_ir_maisto_ūkis_2015.pdf

10. http://www.vic.lt/?mid=467\&id=26038 (Accesed on 20171108$)$ 